\title{
Igor Stravinsky and Russian Preliterate Theater ${ }^{1}$
}

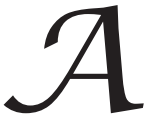

$\mathrm{t}$ the beginning of Petrushka, a tune is heard first in the bass at rehearsal number 2 and then in the full orchestra at 5, with the stage direction: "There passes, dancing, a small crowd of drunken carousers." Western sources, such as Eric Walter White's Stravinsky: The Composer and His Works, identify this tune as "an Easter Song known as the 'Song of the Volochebniki' from the province of Smolensk."” This

1 Originally published in 19th-Century Music 6 (Spring 1983): 232-40, and in Confronting Stravinsky: Man, Musician, and Modernist, ed. Jann Pasler (Berkeley: University of California Press, 1986), 3-15.

2 Eric Walter White, Stravinsky: The Composer and His Works (Berkeley: University of California Press, 1966), 162. White cites Stravinsky's sources from Frederick W. Sternfeld, "Some Russian Folk Songs in Stravinsky's Petrouchka," which initially appeared in Notes (Music Library Association) 2 ${ }^{\text {nd }}$ ser., vol. 2, no. 2 (March 1945): 95-107 and was reprinted in the Norton Critical Scores edition of Petrushka (New York: W. W. Norton, 1967), 203-15. The same identifications are also cited in Vera Stravinsky and Robert Craft, Stravinsky in Pictures and Documents (New York: Simon and Schuster, 1978). All these authors repeat Sternfeld's out-of-focus translations of Russian song titles ("Song of the Volochebniki" instead of "Easter Carol" and "Down in the Petersky" instead of "Along the St. Petersburg Road") and cite his nonexistent geographical locations ("Totemsk" and "Tombosk" instead of the correct Tot'ma and Tambov; the spurious forms are attributable to the inability to distinguish Russian nouns from their adjectival derivations). [Actually, Sternfeld was aware of the more idiomatic translation in the first example, as he had written "Down the Petersky or Petersburg Road" (Notes, p. 100), while White and Craft, evidently relying on him, chose to reproduce only the more literal, less idiomatic variant.-Ed.] Sternfeld and those who rely on his identifications fail to distinguish between rural folk songs of anonymous origin and the urban popular ditties whose authorship can be established and that Stravinsky also quotes in his score. Thus, the organ-grinder's melody, first stated in a disjoined form by clarinets in octaves two measures after 10 and at 12 and then fully at 15, is the sentimental romance, "Toward Evening, in Rainy Autumn," whose text was written by Aleksandr Pushkin (at the age of fifteen). The music was composed by Nikolai Titov. [The situation is actually a bit more complicated: the young Pushkin's poem, published in 1827, was set by two composers of sentimental 
information is correct, though confusingly expressed. The volochebniki, also known as the lalyn'shchiki, were people who went around Belorussian villages on the Monday after Easter Sunday singing volochebnye pesni, that is, Easter carols. The cited identification is thus tautological because it says "an Easter song known as the 'Song of the Singers of Easter Carols."”

In Russian, the carol is known as "Dalalyn'." A look at its lyrics as cited by Irina Vershinina reveals the humorous implications of Stravinsky's placement of the tune in Petrushka. ${ }^{3}$ The passing carousers have to be out-of-towners because the custom of Easter caroling existed only in Belorussia, in areas bordering on Poland, and was unknown in St. Petersburg, where the action of Petrushka takes place. In their drunken state they are disoriented both geographically, thinking they are in their native Belorussian village, and chronologically, confusing the pre-Lenten Carnival with the Monday after Easter Sunday, still six weeks away, on which their announcement that Christ has arisen and request for Easter eggs would be customary and appropriate.

This very small example illustrates how familiarity with Russian cultural background can enhance our understanding of Stravinsky's music. I had occasion to realize the truth of this during the twelve years it took me to write a survey of Russian drama from its prehistoric beginnings to the age of Pushkin. In studying indigenous forms of Russian drama,

romances, Titov and Nikolai De Witte (both in 1829). The melody in Petrushka, however, was neither Titov's nor De Witte's, but one that circulated in Russia from mouth to mouth in many guises, best known as a song of the post-Decembrist period with words by Fyodor Glinka, "No City Noise is Heard" (Ne slyshno shumu gorodskogo). See R. Taruskin, Stravinsky and the Russian Traditions (Berkeley: University of California Press, 1996), 701-4.-Ed.]

3 Irina Iakovlevna Vershinina, Rannie balety Stravinskogo [Stravinsky's early ballets] (Moscow: Nauka, 1967), 73. Stravinsky found this song in Nikolai Rimsky-Korsakov's collection of arrangements Sto russkikh narodnykh pesen dlia golosa sortepiano, soch. 24 [One hundred Russian folk songs for voice and piano, op. 24], where it appears as no. 47. The translation of the cited portion of the text, with ellipses filled out in brackets, is: "Easter carol, Easter carol! [Give us] each an Easter egg! Christ is risen." In the remainder of the text the singers threaten to harm the livestock of those who fail to offer them gifts of holiday foods. See N. A. Rimskii-Korsakov, Sto russkikh narodnykh pesen (St. Petersburg: V. Bessel, 1877, repr. Moscow and Leningrad: Muzgiz, 1951), 90-91. 
I kept stumbling on phenomena that were familiar from Stravinsky's oeuvre between 1910 and 1918. Conversely, examining his output from that period, I saw that his stage works from Petrushka to Histoire du soldat (The Soldier's Tale) add up to a compendium of the native theatrical genres of old Russia.

Prior to the introduction of literary drama, in the form of amateur theatricals in Orthodox religious seminaries (school drama) and at the court of Tsar Alexis (German-derived court drama) during the last quarter of the seventeenth century, dramatized rituals and folk entertainments that can be collectively described as Russian preliterary theater had existed in postbaptismal Russia. With some allowance for mutual contamination between categories, this theater existed in the following forms: (1) enactments of surviving pagan rituals that dated back to pre-Christian times, initially had agrarian significance, were timed to the change of seasons, and were usually (though not always) disguised as Christian holidays or ceremonies; (2) highly dramatized village customs of betrothal, wedding, and postwedding celebration, which also combined pre-Christian and postbaptismal elements; and (3) performances by itinerant folk entertainers, the skomorokhi, Russian minstrels who also doubled as buffoons, musicians, and animal impersonators.

In addition to these three forms of folk theater that go back to Kievan Russia and earlier, there existed in post-Petrine Russia the institution of (4) pre-Lenten Carnival (maslenitsa, maslenichnoe gulianie), with its bearded carnival barkers, puppet shows, masked mummers, and trained bears; and (5) the performances of orally transmitted folk plays about peasants, devils, and foreign royalty that were put on by illiterate soldiers and by convicts in Siberian penal settlements. If we consider Stravinsky's major works for the period 1910-18, we can see that The Rite of Spring (Vesna sviashchennaia, Le sacre du printemps) is a musical dramatization of the first of these categories-a pagan seasonal agrarian rite; Svadebka (The Wedding) sets to music the second of our categories; Renard (Baika pro lisu) is, as most Soviet commentators have realized, a modern revival of the spirit of the skomorokhi; Petrushka, apart from its protagonist's drama, is a catalogue of maslenitsa customs; and Histoire du soldat, despite its Swiss disguises, shares features with the soldier and convict folk drama. 
Why this musical innovator chose to compose some of his most revolutionary works on subjects taken from archaic and, in his day, mostly defunct preliterary dramatized folklore is a fascinating problem in creative psychology. The years 1907 to 1917 were the time of a great wave of new interest in native Russian art, stripped of the hybridization with Western themes and forms that had predominated in the nineteenth century. Pushkin could write his Russian fairy tales The Tale of the Fisherman and the Fish and The Golden Cockerel on subjects borrowed from the Brothers Grimm and Washington Irving, respectively. His Ruslan and Lyudmila, ostensibly a folktale about Kievan Russia, combines Russian folklore elements with themes drawn from Western chapbook romances and with stylistic mannerisms borrowed from Voltaire and Évariste de Parny, just as the opera that Glinka based on this poem weds Russian and Tatar folk songs to musical textures borrowed from Rossini and Weber. A not-dissimilar procedure was followed, mutatis mutandis, in the pseudo-folk operas, such as Sadko or The Snow Maiden, by Stravinsky's teacher, Rimsky-Korsakov. All this is said not to disparage the artistic quality of Pushkin or Glinka or even Rimsky-Korsakov, but to pinpoint the difference between their view of folklore and the one embodied in the work of Stravinsky and his contemporaries, the Symbolist and Postsymbolist poets and Russian Modernist painters of the first two decades of the twentieth century.

Considered from this angle, Stravinsky's first ballet, The Firebird (Zhar-ptitsa, L'oiseau de feu), is a product of the nineteenth-century aesthetic. The libretto mingles themes from Russian folklore with elements drawn from Chaikovsky's Swan Lake and Fyodor Sologub's play Nocturnal Dances, for which Mikhail Fokine did the choreography one year before he staged The Firebird and which had a plot based on a Brothers Grimm tale. The folk songs in The Firebird come from a reputable folk song collection and are cited verbatim. ${ }^{4}$ They have been selected for their exotic beauty and are couched in the most advanced and elegant musical idiom of the time, French Impressionism, just as Glinka and Rimsky-Korsakov used to set tastefully selected folk melodies in internationally approved musical styles of their day.

4 Vershinina, Rannie balety, 50-52, 58-59. 
The use of musical folklore in Petrushka could not be more different. As Irina Vershinina has pointed out, Stravinsky's Russian contemporaries were actually shocked by what they saw as his lack of selectivity. ${ }^{5}$ Trained musicologists were needed to identify the folk melodies in The Firebird (and later in The Rite), but any Russian child could recognize the tunes that accompany the street dancers, the coachmen, or the nursemaids in Petrushka, because they were as familiar as "Home on the Range," "Three Blind Mice," or "When Irish Eyes Are Smiling." Combined with street vendors' cries, barrel organ ditties, the humorous use of an old Easter carol, and hackneyed waltzes by Lanner, this struck the early Russian listeners of Petrushka as a gaudy, tasteless mixture, leading the young Prokofiev to qualify the musical materials of Petrushka as "rotten trash" (trukha). ${ }^{6}$

In Petrushka Stravinsky had turned his back on both the ethnographic approach and the Western-style sugarcoating of folklore that were implicit in the Russian nineteenth-century musical aesthetic. This process was deepened in The Rite, where, in line with the archaist conception, the musical folklore utilized was largely Lithuanian - that is, not only nonRussian, but non-Slavic (the Balts and the Slavs supposedly had common origins in ancient times). But Stravinsky deformed both the Lithuanian and the Slavic materials with a sovereign freedom in a manner that may be termed cubistic. Lawrence Morton's and Richard Taruskin's best detective efforts were required to discern them at all. ${ }^{7}$

By the time he came to compose Svadebka, Renard, and the remarkable sets of peasant songs and choruses of 1914-19, Stravinsky no longer needed either to cite or to deform folk tunes or popular melodies because he had internalized the structural, modal, and melodic properties of Russian folk music. Pianist Aleksei Lyubimov declared that, in these works, "archaism of melodies and dynamism of rhythms create

5 Ibid., 81-82.

6 Prokofiev's letter to Nikolai Myaskovsky in S. Prokof'ev, Materialy, dokumenty, vospominaniia [Materials, documents, memoirs] (Moscow: Sovietskii kompozitor, 1961), 645. Cited in Vershinina, Rannie balety, 74.

7 Lawrence Morton, "Footnotes to Stravinsky Studies: Le sacre du printemps," Tempo, March 1979, 9-16; Richard Taruskin, "Russian Folk Melodies in The Rite of Spring," Journal of the American Musicological Society 33 (Fall 1980): 501-43. 
an extraordinary impression of a natural grasp of the spirit and style of ancient peasant folklore." ${ }^{\prime}$ All that Stravinsky needed from the folk tradition at this point was the words (usually substandard or in phonetically transcribed dialect) and the subject matter in order to create dazzlingly original Russian music that was free of both ethnography and stylization.

Stravinsky's gradual internalization of Russian musical folklore, traceable from The Firebird to Svadebka, had a linear progression. The resultant manner had clear parallels in internalization of folklore observable in the work of other Russian artists of the period-the paintings of Nataliya Goncharova and Marc Chagall, for example, or the narrative poetry of Velimir Khlebnikov and Marina Tsvetaeva. ${ }^{9}$ Stravinsky's utilization of folk theater forms during the same period does not follow a linear or chronological pattern, and it may therefore be more convenient to examine each individual case, beginning with the most ancient of these forms and going up to the more modern.

\section{The Rite of Spring and Agrarian Vernal Rites}

When the Grand Prince Vladimir decreed the imposition of Christianity as the state religion of Kievan Russia in AD 988, he lacked the power and the communications network to compel all his subjects to abandon their earlier Slavic religion. Christianization was followed by many centuries of dvoeverie, literally, "dual religion," and pagan survivals lingered on in the countryside well into modern times. With the nineteenth-century introduction of anthropology and ethnography, a wide array of seasonal folk customs and games was easily identified as directly descending from ancient rituals for welcoming the springtime and expelling the winter, such as had been common since prehistory among various Indo-European tribes. The cults of sun gods Yarilo and Kostroma (who may have been of Slavic, Finnic or Scandinavian origin) and of the mischievous river

8 On the jacket of Lidiya Davydova's recording of Stravinsky's songs, Melodiia $33 \mathrm{C}$ 10-08133-4 (stereo), 331/3 rpm.

9 See Richard Taruskin, "Stravinsky and the Painters" in Pasler, Confronting Stravinsky, 16-38. 
nymphs (rusalki) and ceremonies of welcoming or expelling them at the onset of spring were practiced in more or less disguised form well into the nineteenth century.

As Vladimir Propp points out, the surviving vernal rites (rusalia) for either welcoming the solar gods or expelling the river nymphs followed a similar format. ${ }^{10}$ The purpose of the expulsion was either to make the local bodies of water safe for a summer of swimming or else to move the rusalki, who represented water, from rivers and lakes to the fields and thus assure an ample harvest. There would be ceremonial songs and processions followed by velichanie, the honoring of a central figure, which corresponds to the episode "Velichanie izbrannoi" in the second part of The Rite, usually translated as "Glorification of the Chosen One." The sun god or the river nymph could be impersonated by people or represented by effigies. Whether the honored entity was welcomed or expelled, the effigy was put to ritual death, either by burning or by tearing to shreds. Propp compares this to ancient cults of dying and resurrected divinities, such as Osiris in Egypt and Adonis and Persephone in ancient Greece, cults that symbolized the return of springtime. To read the descriptions of the Yarilo, Kostroma, and rusalia ceremonies in V. Vsevolodsky-Gerngross's History of Russian Theater (1929), in The Russian Folk Theater by Elizabeth A. Warner (1977), or in Propp's cited book is to understand the longrange origins of the theme and the action of The Rite. ${ }^{11}$

Its immediate, short-range sources are to be sought in the great interest in prehistory and early Slavic religion in Russian arts in the years that immediately preceded the composition of that ballet. The Soviet Stravinsky specialist Valery Smirnov in his 1970 book and Lawrence Morton, apparently independently, in 1979 pointed out Sergei Gorodetsky's cycle

10 V. Ia. Propp, Russkie agrarnye prazdniki [Russian agrarian holidays] (Leningrad: Izdvo Leningradskogo gosudarstvennogo universiteta, 1963).

11 Vsevolod Vsevolodskii-Gerngross, Istoriia russkogo teatra [A history of Russian theater] (Moscow and Leningrad: Tea-Kino-Pechat', 1929), vol. 1, chap. 2, 99-191, contains a detailed account of dramatically enacted pagan rituals that existed in Russian culture well into modern times. Elizabeth A. Warner, The Russian Folk Theater (The Hague: Mouton De Gruyter, 1977), contains accounts of Kostroma, Yarilo, and rusalia ceremonies and their later survivals and transformations. Its bilingual format (Russian texts are copiously cited without translation) makes its use by nonspecialists in Slavic studies difficult. 
of poems about Yarilo, written in 1905-7, as a source of the idea and imagery of this ballet. ${ }^{12}$ This is certainly plausible, but there are several other claimants: Aleksei Remizov's 1907 book about seasonal changes and ancient games connected with them, Posolon' (Follow the sun), for example, or the leading Futurist poet Velimir Khlebnikov's series of visionary narrative poems about Stone Age Russia, published in 1911 and 1912, especially $I$ and $E$, in which a Stone Age maiden is caught in a competition between two rival tribes and condemned to be sacrificed to pagan gods. Another source that would bear more detailed investigation is the essays and paintings of the set designer for The Rite, Nikolai Roerich. He was involved in the project since its inception, and some of his earlier paintings bear titles or depict scenes that are reminiscent of certain episodes in the ballet.

\section{Svadebka and Russian Village Weddings}

The earliest native historical source, the Primary Chronicle, reports the existence of "pagan play acting" and dancing at the weddings of ancient East Slavic tribes. A sixteenth-century text, the Stoglav (Book of hundred chapters), complains of the enduring contamination of Christian weddings by pagan survivals. In the 1850 s and 1960s, six volumes of Ethnographic Studies containing numerous transcribed wedding ceremonies from various regions were published by the Imperial Geographic Society. "The obviously theatrical character, as we understand it, of, for example, the wedding ceremony has enabled many ethnographers to record it in the form of theatrical play ... the entire ceremony abounded in magic spells, incantations and, in general, obvious traces of paganism."13

With a few individual adjustments, the betrothal ceremony, the devichnik (a kind of bridal shower, with unbinding of the tresses and the bride's lament for the loss of her freedom), the blessing of the groom by his parents, and the wedding feast were not spontaneous transactions but

\footnotetext{
12 V. V. Smirnov, Tvorcheskoe formirovanie I. F. Stravinskogo [Igor Stravinsky's artistic development] (Leningrad: Muzyka, 1970), 87; Morton, “Footnotes," 9-16.

13 Vsevolodskii-Gerngross, Istoriia russkago teatra, 81-82.
} 
enactments of a prearranged, prerehearsed script that had been traditional in that particular village for centuries. As Tatyana's nurse puts it in Pushkin's Evgeny Onegin: "They unbound my tresses with weeping / And led me to the church with songs." The actual marriage ceremony, which was a prescribed Christian rite, was the only part of the entire wedding not covered by the local ritual. The ritual's potential for theatrical adaptation has been realized since the eighteenth century, when two of the more successful Russian comic operas incorporated scenes of unbinding the bride's tresses, with texts similar to the one used in Stravinsky's ballet-cantata. ${ }^{14}$ In 1875, a company of noted Russian actors and actresses brought to Paris an opulent staging of a transcript of a village wedding. In 1923, the State Experimental Theater presented in various cities of the Soviet Union a production called The Russian Folk Wedding Ceremony, an entire evening performance that reproduced the same ritual. That was, of course, the year when Stravinsky completed the instrumentation of his Svadebka (for some reason still known in this country under its French title of Les noces).

What Stravinsky got from Pyotr Kireevsky's collection of folk texts was not a group of songs to be set to music, but a complete script of a ritual that was actually a folk play. He then trimmed and rearranged it to suit his purposes. The version he chose was less riddled with pagan survivals than some other recorded versions (for example, there is no part for the Guard or the Polite One, euphemisms for a shaman who took over the priestly functions once the church ceremony was completed). ${ }^{15}$ Still, when the Virgin Mary is commanded to bless the wedding and help comb the bridegroom's hair (at 44) and then is given a direct order by the divided bassos ("Pod' na svad'bu," which is roughly "Off to the wedding

14 The Miller Who Was a Wizard, a Cheat and a Matchmaker (1779), with text by Aleksandr Ablesimov and with a pastiche of popular folk tunes arranged by Mikhail Sokolovsky, and The St. Petersburg Bazaar (1782), text by Mikhail Matinsky and bestknown musical version by Vasily Pashkevich. The wedding customs depicted in these eighteenth-century works and subsequently reflected in Stravinsky's masterpiece continued in certain areas in postrevolutionary times. A number of such traditional songs and ceremonies were collected by Soviet folklorists between 1920 and 1960 and published in Lirika russkoi svad'by [Russian wedding lyrics], ed. N. P. Kolpakova (Leningrad: Nauka, 1973).

15 Vsevolodskii-Gerngross, Istoriia russkogo teatra, 81-82. 
with you!"), we realize that the mother of the Savior is here replacing some ancient fertility goddess. In monotheistic religions, divinities do not get ordered about, but in The Iliad, a warrior could order Aphrodite off the battlefield.

\section{Renard and the Skomorokhi}

In the early sketches for Svadebka, there was to be a role for a skomorokh, the minstrel-buffoon. Skomorokhi used to provide the entertainment at both royal and peasant weddings and are often mentioned in wedding songs. In the final score, at rehearsal number 16 of the first scene, there is mention of a "dashing little skomorokh, running in from another village" to distract the bride from her lamentations. In the C.-F. Ramuz translation, a singing bird replaces the clown. Ramuz's French translations of the three works of Stravinsky that are most closely connected with the lore and spirit of the skomorokhi, namely Pribaoutki, Svadebka, and especially Renard, systematically deprive them of that connection.

Renard is perhaps Stravinsky's least understood work among Western commentators. One gets to read in program notes that this is an Aesopian fable about barnyard animals, and Stravinsky gets praised for his clever imitation of these beasts. Soviet critics, from Boris Asafiev (Igor Glebov) in the early 1920s to Mikhail Druskin in the 1970s, invariably call Renard a skomorosh'e deistvo, a minstrel show or buffoon comedy. At its basic level, Renard depicts four skomorokhi in a pre-Petrine village who put on animal masks to perform a satirical, anticlerical skit about the victimization of a wealthy peasant (the Cock) by a con woman disguised as an itinerant nun (the Fox is a Vixen in the Russian text). The Cock's two fellow peasants, the Tomcat and the Ram, rescue him twice. Then the peasants kill the predator and blame the murder on the hounds of the local noblemen, whereupon the performers remove their masks and demand a payment of a crock of butter for their performance.

The skomorokhi are mentioned in chronicles and sermons since the beginning of recorded Russian history. Despite clerical denunciations, they enjoyed a great popularity as purveyors of humor and satire in old Russia. They ceased to exist as a social class as a result of Tsar Alexis's edicts, which outlawed them in 1648 and, in even harsher terms, in 1657. But they were remembered for centuries in folk songs, folk poetry, wed- 
ding rituals, drama, and opera. Their history has been studied by a number of scholars, most authoritatively by the musicologist Nikolai Findeizen, Stravinsky's occasional correspondent. ${ }^{16}$ His work has been supplemented recently by two very good books on the skomorokhi by Anatoly Belkin and Russell Zguta. ${ }^{17}$

The instruments associated with the skomorokhi were the gudok (a vertically held fiddle), volynka (bagpipes), and gusli (the Russian psaltery). Stravinsky was fascinated with the sound of gusli. In early sketches for Svadebka, he intended to impersonate it with harpsichords and cimbaloms. Cimbalom as gusli is of course central to the conception of Renard (where this instrument is also prominently featured in the Russian text, but not in translations). Stravinsky's most realistic orchestral representation of gusli is in the piano and harp duet in the first trio of Scherzo à la russe (1944; this combination follows the example of Glinka's Ruslan and Lyudmila). He was to return to the gusli sound once more in the 1954 instrumentation of Four Songs (taken from two earlier sets of songs), where the flute, harp, and guitar suggest a skomorokhi-like bagpipe and gusli accompaniment.

16 See his Ocherki po istorii muzyki v Rossii [Studies in the history of music in Russia] (Moscow and Leningrad: Muzgiz, 1928), vol. 1, 145-70. Cf. Nikolai Findeizen, History of Music in Russia from Antiquity to 1800, trans. S. W. Pring, ed. and annotated by Miloš Velimirović and Claudia R. Jensen (Bloomington: Indiana University Press 2008), vol. 1, 113-35 (“The Activities of the Skomorokhi in Russia”).

In addition to being the founder of Russkaia muzykal'naia gazeta [Russian music gazette] (published 1894-1918), Findeizen was an important music historian who published monographs on Glinka, Dargomyzhsky, Grieg, and Anton Rubinstein, and books on early Russian music. Perhaps his most important work is the posthumous two-volume history of Russian music from antiquity to the eighteenth century cited above.

The Russian text of Stravinsky's letter to him, written in 1912, about the plan of The Rite of Spring (apart from a deleted postscript) appears in I. F. Stravinskii: Stat'i $i$ materialy [I. F. Stravinsky: Essays and materials], compiled by L. S. D’iachkova, ed. B. M. Iarustovskii (Moscow: Sovietskii kompozitor, 1973). Portions of the letter appeared in translation in Igor Stravinsky, “The Rite of Spring”: Sketches 1911-1913 (London: Boosey \& Hawkes, 1969). Various excerpts cited by Craft, Vershinina, and Yarustovsky are all from the same letter. Yarustovsky seems to imply that there might be other correspondence between Stravinsky and Findeizen at the Saltykov-Shchedrin Library in St. Petersburg.

17 A. A. Belkin, Russkie skomorokhi [Russian minstrels] (Moscow: Nauka, 1975) and Russell Zguta, Russian Minstrels: A History of the Skomorokhi (Philadelphia: University of Pennsylvania Press, 1978). 


\section{Folk Theater in Petrushka}

The folk-theater components in Petrushka are not as ancient in origin as the ones so far discussed. They mostly date to no earlier than the eighteenth century, and they are also far more accessible to Western audiences. There are two points in this regard that I have not seen discussed. One is the importance of the figure of the long-bearded carnival barker, balagannyi ded, rather lamely translated as le compère de la foire, who appears in the first tableau. These barkers, whose job it was to entertain the crowd and to lure them into the balagany (the makeshift barracks where the various performances took place), spoke in lines of rhymed prose of unequal length, known as raeshnik [pronounced raYOSHnik]. The syncopated, limping rhythms of the raeshnik (rather similar in form to the poetry of Ogden Nash, with its wildly varying line lengths) are conveyed in the flute and oboe figure when the curtain goes up (at 4) in the first tableau of Petrushka. Raeshnik is also the rhythm of the subsequent passages, marked stringendo at 7,17 , and 22 . They usually alternate with the cries of the coal vendor ("uglei! uglei!") that open that tableau. ${ }^{18}$

Raeshnik was also the standard verse of the oral folk theater of soldiers and convicts. Ramuz closely imitated its form in his text for Histoire $d u$ soldat, which makes for an interesting connection between that work and Petrushka. The other point concerns the episode of the maskers in the fourth tableau-men disguised as a devil, a pig, a goat, and (added in Fokine's choreography, though not indicated in the score) a woman. These masks, as both Propp's and Zguta's research suggests, go further back in history than the other customs depicted in Petrushka. ${ }^{19}$ These

18 The identification of the motive of fourths as "uglei! uglei!" ("there's some charcoal!") was made in Vershinina, Rannie balety. The author cites Aleksandr Kastalsky's notations of street vendors' cries, selling coal, herring, and marinated apples, all either jumping up a fourth or filling a downward fourth with lesser intervals. Vershinina demonstrates the derivation from these vendors' cries of the rhythm and the intervals at the opening flute motive and also of the theme of the four cellos at 1 and the oboe solo at bar six of 2. As to the return of the initial motive in the "Dance of the Nursemaids," someone seems to be selling coal and pickled apples while the nannies are dancing.

19 See Propp, Russkie agrarnye, 111 (on the significance of animal disguises) and 116ff. (on cross-dressing of the sexes during winter holidays); and Russell Zguta, "Origins of the Russian Puppet Theater: An Alternative Hypothesis," Slavic Review 33 (December 1974): 712 (on the antiquity of these forms of disguise). 
particular masks indicate connections with both old pagan rites and the usages of the skomorokhi.

\section{The Soldier's Tale and Oral Folk Theater}

The connection of the works so far mentioned with preliterate theater is self-evident. Stravinsky had during the gestation of these works friends and associates who encouraged this interest and could provide him with necessary expertise. The respective roles of Aleksandr Benois and Nikolai Roerich in the creation of Petrushka and The Rite were, as we now know, far more fundamental than Stravinsky remembered when he reminisced about those collaborations in Conversations with Igor Stravinsky. ${ }^{20}$ The possible connection of Findeizen with the subject matter of Svadebka and Renard is a topic that will bear investigation.

Things may seem more dubious in the case of Histoire $d u$ soldat. After all, the only folkloric component here is the tale from Aleksandr Afanasiev's collection, which Stravinsky and Ramuz turned into a musical play and reset in Switzerland. Ramuz, who in his memoirs could not even recall Afanasiev's name and who had no knowledge of any Russian traditions, could not have been familiar with the institution of the oral folk theater of soldiers and convicts, which arose in Russia in the eighteenth century in imitation of literate, professional theater and which still existed in the early twentieth century. ${ }^{21}$

20 In Igor Stravinsky and Robert Craft, Conversations with Igor Stravinsky (Garden City, NY: Doubleday, 1959; repr. Berkeley: University of California Press, 1980), the sections on Roerich, 94-95, and on Benois, 97-98, create the impression that Stravinsky selected these artists to design his ballets after his conception of the two works was formed and his music was almost completed. But, as Stravinsky's letters to Roerich dating from 1910-12 and Valery Smirnov's essay on the role of Benois in the genesis of Petrushka conclusively demonstrate, the two artists participated in creating the ballets they designed from the very inception. Each contributed important ideas for the stage action and musical realization of The Rite or Petrushka, respectively. See Igor Stravinsky's letters to Nikolai Roerich, introduced and annotated by Irina Vershinina, in Sovetskaia muzyka, no. 8 (August 1966): 57-63 and V. V. Smirnov, "A. N. Benualibrettist Petrushki" [A. N. Benois, the librettist of Petrushka], in D'iachkova and Iarustovskii, I. F. Stravinskii, 155-62.

21 C.-F. Ramuz, Souvenirs sur Igor Strawinsky (Paris: Gallimard, 1929), 79. Pierre Meylan in his book on the collaboration between Ramuz and Stravinsky, Une amitié célèbre (Lausanne: Éditions du Cervin, 1962), denies that Histoire du soldat owes anything to Russian folklore (p. 65). Unaware of its Russian ties, Meylan attempts to 
Yet the similarities of Histoire $d u$ soldat to plays of this genre cannot be overlooked. In chapter 11 of part 1 of his semiautobiographical novel Notes from the House of the Dead, Fyodor Dostoevsky described a performance by convicts in a Siberian penal colony of a folk play based on plays and operas about Don Juan, a performance he had actually witnessed in the late 1840s. The play was accompanied by a raucous little orchestra of squeaky violins and balalaikas, and it featured a virtuoso contribution by a tambourine player. Other plays of this type were collected and described in the early twentieth century. Aleksei Remizov, the influential writer, who may have had a hand in the libretto of The Firebird and whom Stravinsky helped out financially in Paris in the 1930s, ${ }^{22}$ based his very successful Comedy of the Devils (1907) on such plays. He later adapted the most famous play of this genre, Tsar Maximilian, popular for almost two centuries in peasant amateur theatricals. Other twentieth-century playwrights, such as Zamyatin and Sologub, also drew on this type of play, whose logic, as Remizov remarked, is the logic of dreams.

Typical of this theater are deformations of foreign legends (Histoire $d u$ soldat is a deformation of the Faust legend, just as the play Dostoevsky saw was a deformation of Don Juan); interactions of common Russian folk (soldiers or peasants) with foreign, non-Russian royalty; the juxtaposition of everyday mundane reality of military barracks or peasant life with the supernatural, usually represented by the devil; and an anachronistic mixture of a fairy-tale world with ultramodern realia, such as the stock exchange, the telephone, tango, and ragtime in Histoire $d u$ soldat. Combined with the French versification that seems to imitate the raesh$n i k$ of Russian folk dramas, these features indicate that the Russian oral folk theater connections of Histoire du soldat deserve to be investigated in greater depth.

\section{Conclusions}

In a telling footnote to Stravinsky in Pictures and Documents, Robert Craft expressed regret that "Stravinsky never explained the anthropological

derive its dramatic conception from French medieval fabliaux. His book repeatedly implies that Ramuz was the author rather than the translator of the texts of Svadebka and Renard, though Meylan is clearly aware of the true facts.

22 Stravinsky and Craft, Pictures and Documents, 642n10. 
background of [Svadebka] ... the rituals and cultural traditions of which Western audiences are largely unaware." ${ }^{23}$ The regret is of course also applicable to the rest of Stravinsky's oeuvre of the 1910s. When he was creating these epochal scores, he was addressing a Russian audience, for which such explanations would have been redundant. Foreign audiences, with whom these works were not yet established, might have been put off by too much ethnography or anthropology in program notes. In later years, Stravinsky was reluctant to discuss the folklore sources of his earlier compositions, not on account of snobbery or reactionary politics, as has sometimes been suggested, but because his artistic tastes had undergone a complex evolution that caused him to lose interest in that whole sphere and also because he had forgotten a great deal. Just how much he forgot can be seen in his discussion in Expositions and Developments of his Podbliudnye (Dish-divination songs). Stravinsky not only mistranslates the title as Saucers but gets the method of divination all wrong, the method that is described quite precisely in Pushkin's Evgeny Onegin, chapter 5, stanza 8 , where the text of the first of these songs is also quoted. ${ }^{24}$ Speak-

23 Ibid., 619n236.

24 As outlined by Propp, Russkie agrarnye, p. 108, dish-divination songs were sung during Yuletide by young women in rural areas as an accompaniment to a special fortune-telling game. The game consisted of placing on the table a large dish filled with water in which each participant would put her ring, comb, or some other small trinket, after which the dish was covered with a towel. Next came the singing of the podbliudnye (literally, "in the presence of the dish") songs, whose texts dealt with allegorical descriptions of agricultural activities, gigantic symbolic animals, and possession of gold, jewels, and other treasures. Most of these songs featured the obligatory refrain of "slava!" or "slavna!” ("glory!” or "glorious!”). During the singing, the trinkets were extracted one by one from under the towel over the dish, and as each trinket was withdrawn, its owner's fortune was predicted in accordance with the imagery of the line being sung.

In addition to studies by folklorists, such as Propp, this divination game was described in two of the best-known Russian literary works of the early nineteenth century: Pushkin's Evgeny Onegin and Vasily Zhukovsky's much-anthologized romantic ballad Svetlana (1812). Stravinsky himself, after completing his four dish-divination choruses (composed between 1914 and 1917), returned to this genre once more in 1919 in the third of his Four Russian Songs for voice and piano, which bears the title Podbliudnaia and has the typical refrain of "slavna!" Yet, discussing these choruses with Robert Craft in Expositions and Developments (Garden City, NY: Doubleday, 1962; repr. Berkeley: University of California Press, 1981), pp. 118-19 in the 1981 edition, Stravinsky stated: "Choruses of this sort were sung by the peasants while fortune-tellers read their fingerprints on the smoke-blackened bottoms of saucers." 
ing of Renard in the same book, Stravinsky cannot remember the Russian title of this work and confuses the "Russian" gusli with the Yugoslav bowed instrument, the guzla. ${ }^{25}$

This is either an aberration of memory or an ad hoc invention. No such method of fortune-telling is associated with podbliudnye songs by any Russian poet or student of folklore (nor does it seem likely that reading fingerprints was known to Russian peasants in the eighteenth and nineteenth centuries). The saucers, whose mention by Stravinsky has saddled these choruses with their unsuitable English title, may have come from his confusing the Russian word for dish (bliudo) with the one for saucer (bliudtse). Or Stravinsky may have been thinking that the English saucer had the same meaning as the French sauciere. Be that as it may, the statement in Expositions and Developments had added further cultural barriers to appreciation in the West of this lovely choral work, made even more attractive by Stravinsky's 1954 rearrangement of it for voices and four horns.

Even a person as close to Stravinsky as Robert Craft is quite at sea about what the titles of the individual choruses should be. He calls the first of them "Saints' Day in Chigisakh" or "Christ in Chigisakh" or "Chigisakh across Yauza" in Stravinsky in Pictures and Documents, 604. In all three versions the name of the village Chigisy [recte: Chigasy] appears in the locative case, which suggests that Craft's informants did not know Russian grammar. [Chigisy, the erroneous form of the town's name, was Stravinsky's (not SK's) error, maintained in all autographs and editions._-Ed.] This is the song cited in Evgeny Onegin. In his commentary to his translation of this novel, Vladimir Nabokov (vol. 2, 497) includes the correct translation of the title, which is "In Our Savior's Parish in Chigasy beyond the Yauza," and of the entire text. There is no way of knowing from the existing English translations that the song opens with a description of a brick church built in 1485 and ends with a portent of death, information which Nabokov supplies.

The 1932 J. \& W. Chester edition of Podbliudnye accompanies the title of the second chorus, "Ovsen"," with a note that this is "a beneficent solar deity honoured in Russian mythology." Eric Walter White repeats this information in Stravinsky, 211, though no study of pre-Christian Russian mythology mentions any such being. Robert Craft, Pictures and Documents, calls this chorus "Autumn," apparently because his informants have confused "Ovsen" with osen', which indeed means autumn. This is a particularly absurd mistake because a check with Vladimir Dal's standard Dictionary of the Great Russian Language (4 vols.; first published 1863-66) shows that ovsen', known in some areas as avsen' or tausen', was the name of the first day of spring in the pre-Christian Russian calendar, according to which the new year began on the first day of March. Although the meaning was lost in later centuries, the word remained in some peasant songs as an exclamation that conveyed the hope for a good harvest (see Propp, Russkie agrarnye, 38-39).

25 The Russian title of Renard, printed in recent editions of the score, is Baika (a regional word for story or fairy tale). The first edition had a more extended title that means "The Story of the Vixen, the Cock, the Tomcat, and the Ram." In Stravinsky and Craft, Expositions and Developments, p. 119 in the 1981 edition, Stravinsky, claiming to cite the original Russian title of this work, begins with a different word for fairy tale, skazka (which is the first word in the Russian title of Histoire du soldat), 
During the years when Stravinsky was sharing his reminiscences with Robert Craft, his energies were still occupied with creating more new music. If the choice were between total recall of his Russian period and the composition of Agon, The Flood and Requiem Canticles, we would all surely choose music over documentation and memories. But now that Igor Fyodorovich is gone, those of us who know something about Russian culture must try to supply the missing pieces.

This dazzling piece displays with equal zest and magnificence both SK's erudition and his capacity for exciting speculation; and one of us (RT) must sacrifice decorum and revert to the first person in this commentary. It gave me an unforgettable thrill when I heard it in its original form, as a contribution to a roundtable on Stravinsky's Russian backgrounds at a Stravinsky centennial conference at the University of California, San Diego in September 1982. It was my first glimpse of SK in person, and no first meeting with a fellow scholar has ever been for me more rokovoi-to use that resonant Russian word not in its frequent meaning of "leading to disaster," but in the one that relies more on the literal meaning of the root noun, which means "fate." I knew that SK was someone with whom I would be fated to interact repeatedly and profoundly, for he had in this brief piece mapped out the territory I was to inhabit for the dozen-plus years that it took me (eerily mirroring the "twelve years it took me to write a survey of Russian drama" that SK invoked at the outset) to complete and see through to print the huge monograph, Stravinsky and the Russian Traditions, on which I had then just embarked. Every one of SK's examples has its chapter counterpart in that book, and, with the one exception duly to be noted, I found his spadework to be a trusty guide (to typology in the first place), without which my work would have been far more arduous and far less coherently concluded. The whole central section of my book, devoted to what is sometimes called Stravinsky's "Swiss period,"

and follows it with the wrong preposition, which puts the four animals (with the Cock preceding the Fox) in a different grammatical case from the one they were in in the first edition. The South Slavic guzla (possibly suggested to Stravinsky by Prosper Mérimée's volume of faked Yugoslav poetry, La guzla, which Pushkin translated into Russian) has nothing to do with the Russian psaltery, gusli, which inspired the sonority of Renard. 
is in effect a gloss on SK's conference paper of 1982, and on its slightly more elaborate published version.

The Swiss period, for Stravinsky, encompassed the years 1910 to 1920, the years during which he was living in the Vaud, the French-speaking southwestern canton of Switzerland abutting Lake Geneva (or Leman, as it is locally known), where he repaired originally for the sake of the excellent maternity facilities its hospitals offered his pregnant wife (his son Soulima having been in utero at the time of the Firebird premiere and the removal of the whole family to Paris to witness it), where he then decided to make his base in the period of his wild early successes via Diaghilev's Russian Ballet, and where, finally, he chose to sit out the upheavals of World War I. In one of the few passages from his Chroniques de ma vie that can be quoted with confidence, Stravinsky's ghostwriter wrote, "My profound emotion on reading the news of war, which roused patriotic feelings and a sense of sadness at being so distant from my country, found some alleviation in the delight with which I steeped myself in Russian folk poems." ${ }^{26}$ Brought on by homesickness, it was the most intensely nationalistic phase of Stravinsky's career, but, as SK very acutely points out toward the beginning of his essay, the nationalism that informs Stravinsky's Swiss-period music is of a very different sort from the familiar nationalism of nineteenth-century Russian art, as embodied musically in the work of the group that included his teacher, Rimsky-Korsakov. That difference was summed up in a single inspired sentence by Stravinsky's exact contemporary, Yakov Aleksandrovich Tugendhold (1882-1928), a Russian art critic living in Paris, who sent a review of Firebird back home to the Symbolist journal Apollon. "The folk," he wrote, "formerly the object of the artist's pity, are becoming increasingly the source of artistic style." ${ }^{27}$

Art historians have long had a name for this phenomenon, which showed up first and most distinctly (and was most widely practiced) in the visual and, particularly, the applied arts; and it is no accident that Tugendhold was commenting as an art historian on the visual aspects of the Russian ballet (in the case of Firebird, the sets and costumes of Konstantin Korovin and Aleksandr Golovin). The word art historians have coined is neonationalism. It was not a term anyone had ever applied to music, because hardly any musicians had been affected by the tendency. Until Stravinsky, that is, who learned of the

26 Igor Stravinsky, An Autobiography (New York: Simon and Schuster, 1936), 83.

27 Ia. A. Tugenhold [sic], "Russkii sezon v Parizhe," Apollon, 1910, no. 10, p. 21. 
tendency from the painters with whom he was now willy-nilly collaborating, and who took it further than any other artist in any other medium, making it, in the process, more determinative of his own personal style during his Swiss years than anyone had done before or since.

I was in San Diego that fateful morning to give a paper in which I proposed that the term neonationalism be applied to Stravinsky at last-and, through him, employed as a lens for viewing and comparing the work of other composers. Imagine my combined delight and resentment to hear SK, who went immediately before me on the panel, steal my thunder, very accurately invoking neonationalism (in all—-thankfully—but name) in detailing the crucial difference between the music of Firebird and that of Petrushka.

It is because the music of this most intense nationalistic phase of Stravinsky's career was composed with a Russian audience in mind but was for many decades published only abroad and performed only before foreigners that the anomaly arose of which SK complains when he notes that Svadebka is "for some reason still known in this country under its French title of Les noces." Believe me, he knew the reason. But he refused to accept the strange convention (which applies as well, of course, to Pétrouchka and Le sacre du printemps and even, often, to L'oiseau de feu, not to mention the "Swiss" songs (Pribaout$k i$, Berceuses du chat, and all the rest), maintaining a stubborn stance that bedeviled the lives of many editors in his time, and led to the shelving of at least one important piece of work..$^{28}$ I was younger and less exigent, but warmly sympathized with SK's crusade.

28 SK addressed the subject in correspondence with his editor as he prepared an article about Diaghilev. "Now we come to a point about which I have very strong feelings. That is the outmoded custom of regarding works of Russian art, music, ballet, etc., as somehow more authentic if their names are cited in French. This was a snobbish British custom until ca. the 1920s, but I hoped that it had faded away. It makes no sense in the world to cite ballets by Russian composers, which have familiar and wellestablished names in English, in any form but the English. To put them into French or to add French diacritics not needed in English strikes me as a form of antiquated snobbery (as if English were not as cultured a language as French).... I would feel like a fool if an article I've signed follows that meaningless custom.... I couldn't live with myself if we Gallicize The Firebird, Petrushka, The Rite of Spring, The Prodigal Son, Cleopatra and Scheherazade. This would make me guilty of the kind of pretentious snobbery that I've been battling for years... As to Fokine, I bow to the customary French e muet at the end of his last name (redundant in English), but his first name must be Mikhail (as in Baryshnikov) and that of Benois should be Alexander. Please accept my assurance that Russian names do not become less authentic when put into 
The one point on which SK's brilliant typology of preliterate theatrical genres requires correction is in the matter of Renard (or as he would prefer, Baika pro lisu, petukha, kota da barana), about which he confidently asserted that it was, "as most Soviet commentators have realized, a modern revival of the spirit of the skomorokhi," the medieval Russian jongleurs or Spielmänner. Agreeing with the Soviets must have given SK a peculiar sensation, and perhaps it should have tipped him off: Asafiev's idea was a speculative hypothesis, and it has not been borne out by subsequent research. ${ }^{29}$ Which is not to say that one must not think of the word skomorokh when watching or listening to Renard, only that there is no demonstrable connection between the skomorokhi and the preliterate Russian theater. They are not known to have engaged in dramatized performances, and so when SK writes that

at its basic level, Renard depicts four skomorokhi in a pre-Petrine village who put on animal masks to perform a satirical, anticlerical skit about the victimization of a wealthy peasant (the Cock) by a con woman disguised as an itinerant nun (the Fox is a Vixen in the Russian text). The Cock's two fellow peasants, the Tomcat and the Ram, rescue him twice. Then the peasants kill the predator and blame the murder on the hounds of the local noblemen, whereupon the performers remove their masks and demand a payment of a crock of butter for their performance,

he is describing something that never happened in a pre-Petrine village, but only in a community of Stravinsky's (or Asafiev's) imagination. And so we should bear in mind that SK spoke not of the skomorokhi but of their "spirit," as Asafiev (and perhaps Stravinsky, too) imagined it. Nor is there any historical reason to suppose that the skit enacted in Renard was supposed to be allegorical, as SK asserts. He claimed a bit less, interestingly enough, when reading the paper aloud in San Diego. On that occasion he told his audience (according to Robert Craft's chance citation from the unpublished typescript) only that "Renard is a work that portrays a group of itinerant skomorokhi

English rather than French.” SK to Karen Kevorkian/Ann Karlstrom, 22 August 1988, carton no. 7, Simon Karlinsky Papers, BANC MSS 2010/177, The Bancroft Library, University of California, Berkeley. (The reader will have realized that for the present republication of SK's articles, we have generally used the [transliterated] Russian form of names.)

29 For a thorough review of the evidence, see Taruskin, Stravinsky, 1237-46. 
who don animal masks, perform a satirical, anticlerical skit for a rural audience in pre-Petrine Russia and demand a payment in barter at the end of the performance." ${ }^{130}$ Even without the wealthy peasant and the con woman, this probably goes beyond what Stravinsky actually intended to portray-not a satire, just a veseloe predstavlenie, a "merry performance," as the work's subtitle would have it-and yet SK's version winningly displays his playful, speculative side, and I am glad it is in print. Similar strictures might be offered by strict-constructing historians to some of SK's other interpretive sallies, like the connection he draws (plausible from the Slavist side, less so from that of Stravinsky's biography) between Histoire du soldat and convict drama; and at times he reads the fruits of his own erudition a bit literalistically. (Did Stravinsky know or care that "Dalalyn', dalalyn"' was Belorussian? Did he expect his listeners to know?) But the speculations of a well-stocked imagination, verifiable or not, offer nonmatriculated listeners or spectators an enriched

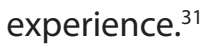

30 Quoted by Craft in Stravinsky: Selected Correspondence, vol. 1 (New York: Alfred A. Knopf, 1984), 421n.

31 One last footnote may be the place to record the fact that (pace SK) Mikhail Semyonovich Druskin (1905-91), the musicological doyen of the Leningrad Conservatory who preserved an island of St. Petersburg there for the benefit (and to the gratitude) of his pupils, and who as a young Soviet pianist performed Stravinsky's Concerto for Piano and Winds in the composer's presence (Berlin, 1926), actually resisted Asafiev's interpretation of Renard, even though Asafiev had been his mentor. Nowhere in Druskin's monograph Igor' Stravinskii: Lichnost', tvorchestvo, vzgliady (Leningrad: Sovetskii kompozitor, 1974) did he mention skomorokhi in connection with Stravinsky's "merry performance," which deprived him of an easy way of characterizing the piece. In one place he calls it a "circus acrobatic performance" (p. 74), in another a "vulgar fairground spectacle" ("ploshchadnoe iarmarochnoe zrelishche," p. 92). 